\title{
Relação solo-água-vegetação em uma toposseqüência localizada na Estação Ecológica de Assis, SP
}

\author{
Carlos Eduardo Pinto Juhász
}

\section{Resumo}

O bioma Cerrado está cada vez mais fragmentado devido à ocupação agrícola e antrópica. Para a manutenção da biodiversidade, corredores de vegetação devem ser criados com o auxílio da revegetação e recuperação de áreas degradadas. Isto é facilitado pelo conhecimento da distribuição e dinâmica natural dos solos. O objetivo deste trabalho foi caracterizar o funcionamento físico-hídrico dos solos distribuídos em uma toposseqüência sob vegetação nativa. A área de estudo foi localizada dentro de uma parcela permanente instalada na Estação Ecológica de Assis, SP, Brasil, com vegetação predominante de cerradão ou savana florestada. Para a caracterização do funcionamento físico-hídrico dos solos foram realizados inicialmente estudos morfológicos, a partir da técnica da análise estrutural e da descrição de perfis de solo dispostos em cinco posições-chave da encosta. Amostras deformadas de solo foram utilizadas em análises químicas, granulométricas e densidade de partículas. Amostras indeformadas coletadas em anéis cilíndricos definiram as curvas de retenção de água e a densidade do solo. Blocos de solo foram impregnados e polidos para análise de imagens, obtendo-se a distribuição de poros em número, forma e tamanho. Em poços perfurados em três setores da toposseqüência, foi determinada a condutividade hidráulica saturada de campo. O monitoramento da umidade do solo "in situ" foi obtido por sensores instalados nos principais horizontes das trincheiras, calibrados para cada horizonte, durante o período de novembro de 2003 a novembro de 2004. Foram também utilizados os dados de precipitação mais próximos. Fotografias digitais adquiridas nos perfis de solo determinaram a distribuição das raízes. Os solos foram classificados, de montante a jusante, em Latossolo Vermelho, Latossolo VermelhoAmarelo, Latossolo Amarelo e Gleissolo Háplico, com transição homogênea de cor e predomínio de textura franco-arenosa. No horizonte de superfície da toposseqüência, pequeno número de poros complexos de diâmetro equivalente superior a $1000 \mathrm{~m}$ ocupou quase a área total da imagem, representando uma estrutura de empilhamento de grãos simples com porosidade maior que em profundidade. Este comportamento provocou uma menor retenção hídrica, apesar do maior teor de matéria orgânica, e oscilação da umidade do solo após cada evento chuvoso. Predominaram raízes aglomeradas ou ramificadas nesta camada. Em profundidade, as raízes são mais individuais. Nos Latossolos, maior número de poros complexos de diâmetro equivalente superior a 1000

m ocupa menor área em Bw do que em superfície. Isto indica a presença de aglomerados de microagregados em $\mathrm{Bw}$ que conferem maior retenção de água, maior número de microporos e menor oscilação da umidade do solo do que em superfície. No Gleissolo, o horizonte Btg2, mais profundo e mais argiloso, apresentou estrutura mais densa representada por uma porosidade expressiva de forma arredondada ou cavitária de diâmetro de 30 a 1000 m. Neste horizonte, foi obtida a maior retenção hídrica, drenagem imperfeita e menor condutividade hidráulica. Nos outros horizontes da toposseqüência a condutividade foi elevada. O relevo influenciou nas propriedades físico-hídricas e morfológicas dos solos que, por sua vez, determinaram o conteúdo de água limitante na estação seca e em períodos de estiagem. Este comportamento pode definir o padrão florístico de cerradão na parcela permanente.

Palavras-chave: Cerrado, Latossolo, vertente, água no solo, retenção de água, umidade do solo, porosidade, análise de imagens, distribuição de raízes

\section{FICHA CATALOGRÁFICA}

Juhász, Carlos Eduardo Pinto

Relação solo-água-vegetação em uma toposseqüência localizada na Estação Ecológica de Assis, SP -Piracicaba, 2005

110p.:il.

Dissertação (Mestrado) - Escola Superior de Agricultura Luiz de Queiroz, 2005.

1. Cerrado 2. Curva de retenção 3. Latossolos 4. Porosidade do solo 5. Relação solo-água-planta 6. Umidade do solo I. Título

CDD 631.432 